\title{
Private Online Workspaces for Doctoral Learners - Enhanced Communication and Reduced Isolation
}

\author{
Ronald Berman and Cathy Ames \\ Grand Canyon University, Phoenix, Arizona USA
}

\author{
ronald.berman@gcu.edu cames1818@gmail.com
}

\begin{abstract}
This quantitative exploratory study, a continuation of the university's four year research initiative that addresses the high national rate of doctoral student attrition, investigates whether a private online workspace for doctoral students and their dissertation committee will enhance communication and reduce learner's feelings of isolation during the dissertation phase. Private doctoral workspaces provide a virtual platform for learner and committee collaboration, manuscript review, and milestone planning. The purpose of this study is to offer preliminary feedback to guide in the further development of the virtual workspace. To assess effectiveness of the private doctoral workspace, a seven question online survey was created to address usage, communication, and isolation. Two surveys were distributed to 803 doctoral candidates at a private southwestern university in the United States, resulting in 328 respondents for the first survey, and 190 respondents for the second survey. Doctoral learners completed the survey at the onset of the private doctoral workspace implementation, and again four months later. The results indicate that doctoral learners regularly access their private dissertation workspace, communicate more frequently with their dissertation committee, and have reduced feelings of isolation. These results may provide similar benefits to other academic groups working together on long-term projects in other disciplines.
\end{abstract}

Keywords: attrition, communication, dissertation, dissertation committee, doctoral community, network, isolation, private doctoral workspace, retention

\section{Introduction}

Despite continued growth in online enrollment and advances in educational technology, doctoral attrition has remained alarmingly high for decades, between $40 \%$ and $70 \%$ (Lovitts, 2001). According to Lovitts (2001), doctoral learners often feel unequipped for the rigors of doctoral programs. In the United States a dissertation is required for program completion and is equivalent to an international thesis. Although many doctoral learners finish their doctoral coursework and obtain candidacy, they fail to complete their dissertation; this occurrence is so common that it is

Material published as part of this publication, either on-line or in print, is copyrighted by the Informing Science Institute. Permission to make digital or paper copy of part or all of these works for personal or classroom use is granted without fee provided that the copies are not made or distributed for profit or commercial advantage AND that copies 1) bear this notice in full and 2) give the full citation on the first page. It is permissible to abstract these works so long as credit is given. To copy in all other cases or to republish or to post on a server or to redistribute to lists requires specific permission and payment of a fee. Contact Publisher@InformingScience.org to request redistribution permission. called, "All But Dissertation (ABD)."

Many learners drop out before completing their dissertation due to unclear expectations, lack of communication, and feelings of isolation (Golde, 2005).

Smallwood (2004) refers to the issue as a "scandal" and writes that it is a fundamental problem in doctoral education in the United States. Attrition is a multifaceted problem, affecting institutions and students nationwide. 
Online classes are growing in popularity (Allen \& Seaman, 2011), and addressing the unique needs of distance learners is a challenge for university leaders of doctoral programs. While campus opportunities provide interaction for learners, online learners do not have a similar opportunity, which can create a physical distance barrier (Bollinger \& Inan, 2012). To accommodate the distinctive needs of online doctoral learners, the focus is shifting to psychosocial aspects of integration; this includes offering technology based tools for learners to connect with peers and faculty members to create a sense of community (Bollinger \& Inan, 2012). Academic leaders are tasked with developing new approaches and providing tools to address the evolving needs of distance learners.

In 2010, university leaders from a university in the southwestern United States introduced a multi-year research initiative to address the growing national concern of online doctoral learner attrition. To facilitate this research initiative, the Doctoral Community Network (DC) was developed. The DC is a learner driven, online scholarly community designed to help doctoral learners successfully complete their dissertation and program of study. In a single virtual location, the DC provides a comprehensive catalog of support services to guide and assist new researchers as they learn the terminology, tools, and norms to become independent scholars, capable of producing high-quality research. Learner access provides timely content written by experts in the fields of quantitative research, qualitative research, and technology. Experts include those in higher education, $\mathrm{K}-12$, psychology, and business. Using a collaborative technology, the DC provides a mechanism for new researchers to receive feedback on prospective research ideas from a nationwide research community. Research anxiety is more common in learners using online formats (DeVaney, 2010), and using the DC may mitigate research anxiety in distance and novice researchers. Once learners post research questions and ideas to the DC, other students, faculty, and the full-time doctoral librarian offer feedback, suggestions, and references.

In 2012, 463 doctoral learners responded to a survey distributed by leaders of a university in the southwestern United States to 2600 doctoral learners. The results were very promising as $75 \%$ indicate that DC can help them complete their research and dissertation, $79 \%$ state that DC enhances their overall doctoral experience, and $74 \%$ state that they are satisfied with the DC (Radda $\&$ Berman, 2012). In yet another study to a smaller sample of doctoral graduates (Berman, Radda, $\&$ Cross, 2013), it was learned that doctoral graduates who logged onto the DC more than one time per week reported reduced isolation when compared to other doctoral learners who did not logon at least one time per week. Together these preliminary results suggested that the college's approach and implementation was sufficient to warrant expansion.

In 2014, the university expanded the DC to include support exclusively for doctoral learners working on their dissertation. The university augmented the DC with private doctoral workspaces enabling doctoral learners to share manuscripts, track milestones, and communicate with committee members. In addition to being a repository for dissertation related documents and versions, all communication within the private doctoral workspace is maintained until learners complete their dissertations. Prior to developing the private doctoral workspace, the dissertation communications process was disjointed, limiting faculty and dissertation committee oversight. Faculty and learners communicated almost exclusively through email, and faculty and dissertation committee members were unable to easily ascertain the doctoral learner's progress and dissertation development. The private doctoral workspace was established to facilitate communication and progression of doctoral learners as they interact with their committee members and other involved faculty. The private doctoral workspace is unique compared to other reference and communication systems. The private doctoral workspace is specifically designed to support the needs of novice doctoral researchers who are learning to research and require assistance during the dissertation process. The dissertation process is often not fully understood by doctoral learners (Golde \& 
Dore, 2001), and the doctoral workspace provides links to dissertation resources, templates, and video tutorials. These resources help doctoral learners navigate dissertation process.

The purpose of this quantitative study is to develop an understanding of doctoral learners who use the private doctoral workspace during their dissertation, their reported usage, committee communication, and their overall feelings of isolation. This study investigates whether the creation of a private online workspace for doctoral students and their dissertation committee can, within a short time frame, enhance committee communications and connectivity, while also reducing learner isolation, which often appears during the dissertation phase.

\section{Literature Review}

\section{Doctoral Attrition is a Persistent Problem}

The Council of Graduate Schools (2010) reported as few as 57\% of Ph.D. students complete their program within 10 years, and, according to Fiegener (2011), there has been a decline in doctoral degrees. Even students who are highly proficient at their coursework often drop out, particularly during the dissertation phase. Doctoral learners often feel unprepared for the rigors of the dissertation. Students succeed at coursework but often fail to complete their dissertation, even though there is little academic difference between completers and non-completers (Lovitts, 2001). While some attrition is expected, student retention in higher education is a significant and ongoing problem (Council of Graduate Schools, 2008). The challenge of retaining learners is inherent in doctoral programs.

Social isolation and an unstructured format during the dissertation are major factors in doctoral attrition (Ali \& Kohun, 2007). Independent research can be daunting to novices as they balance working alone and collaborating with their dissertation committee. Moreover, the uniqueness of a student's dissertation proposal makes each experience individual, which mandates working alone to some degree (Ali \& Kohun, 2007). The transition to independent scholarship can be daunting for doctoral learners as they evolve into autonomous researchers. Writing a dissertation requires students to be creative and think in new ways (Lovitts, 2005), which can present challenges. Prior to the dissertation, learners are characteristically enrolled in structured programs, with faculty members to guide them through new experiences. During the dissertation phase, with their newly acquired skills, learners must self-regulate their progress, produce scholarly writing, and navigate the research arena.

Many faculty members acknowledge that the transition to independent research is difficult for students (Lovitts, 2001); therefore, it is essential for learners and dissertation committees to develop a positive working relationship. During the dissertation phase, students require timely communication as inconsistent feedback may create resentment (Ali \& Kohun, 2007). A positive experience depends largely on the quality of interactions students have with instructors. Fostering a communicative culture may enable doctoral learners to experience more success. Completing the dissertation is difficult (Holmes, Robinson, \& Seay, 2010), and Berman, Grant, and Markette (2012) posit that learners often need extra support during the dissertation phase when they encounter unexpected problems, which can intensify their challenges. To maintain success during the dissertation phase, ongoing communication between the learner and their dissertation committee is critical.

\section{Incidence of Attrition is Higher in Online Courses}

Reports indicate online enrollment is increasing; four million students were enrolled online in 2008, a 17\% increase from the previous year (Allen \& Seaman, 2010). In contrast, traditional education grew by only $1.2 \%$ (Allen \& Seaman, 2010). In support of these findings, the 2011 report 
on distance education in the United States claimed 32\% of students in higher education were taking at least one online course (Allen \& Seaman, 2011). Education delivery is rapidly changing, and effective university leaders will find ways to address these changes. Despite this growth, online student retention remains lower than in traditional classrooms. McCracken (2009) states online attrition rates are $20 \%$ to $80 \%$ higher than traditional courses. Online courses provide flexibility for learners and faculty; however, the troubling online attrition rates indicate improvement is needed in online formats. Although online learning is increasing, retention is lower than traditional programs (Hachey, Wladis, \& Conway, 2012). Several studies discuss the difficulties and consequences associated with doctoral attrition; however, the studies receive little attention from doctoral program administrators; as a result, the problems remain unnoticed or marginalized (Lovitts, 2001). Attrition in doctoral learners can be overlooked and can intensify in online formats.

As online education becomes increasingly popular, feelings of isolation rise despite greater availability of collaborative tools. According to Rovai (2002), online students may feel social isolation due to the physical separation between the learner and the institution; consequently, finding ways to effectively engage online learners is warranted. Student-faculty relationships and cohort support are vital to doctoral student success (Stallone, 2011). Online learners have no tangible connection with the physical institution or faculty members, which can lead to feelings of remoteness. As highlighted by Moore and Kearely (2012), communication and psychological distance between the instructor and student becomes difficult to manage in a virtual learning environment. Providing adequate opportunities for communication between learners and instructors may help bridge the distance gap. Online systems have not fully adapted to the new online format (Saba, 2011); consequently, overcoming the barrier of physical space can be difficult for online instructors and learners.

To effectively reach students, online instructors not only have to teach, but they must also try to bridge the differences in space, time, and perception that come with online education delivery (Greenberger, 2012). Online instructors are responsible for addressing challenges that can hinder distance learners. Allen and Seaman (2011) found 65\% of higher education institutions indicated online learning was critical to their long-term strategy. As online enrollment has grown, so has interest in retaining online students. Increasing learner engagement and regular communication may assist in reducing isolation, resulting in higher retention of online learners. Interaction between students and instructors is vital (Sull, 2013); although doctoral students are experienced learners, they need meaningful engagement and guidance as they begin the dissertation phase of their program. Lack of communication can hinder persistence in online learning; leaders can implement methods that offer opportunities for students to communicate and collaborate, increasing the likelihood of developing a sense of community (Rovai, 2002). Based on this premise, it is essential that institutions actively foster collaboration among faculty and students to increase student persistence. Baker, Pifer, and Flemion, (2013) posit that students are aware of the need to develop networks, but isolation presents challenges to fostering connections. Learners who feel isolated, and fail to integrate fully into the autonomous dissertation phase, are at risk of dropping out.

The transition from novice researcher to an independent researcher can be challenging for learners, as they are required to mature from knowledge consumption to active fieldwork (Lovitts, 2001). The dissertation phase requires doctoral students to transition from being dependent learners participating in graduate level courses with a pre-defined syllabus, to independent learners creating new knowledge through research. Learners assert that the doctoral process is complex and isolating, and information can be difficult to find (Golde \& Dore, 2001).University administrators seeking to improve doctoral retention during the dissertation phase must be aware of the challenges for doctoral learners. 


\section{Summary}

Learner support and collaboration is essential when students complete their coursework and begin to work independently on their dissertation. Isolation is a contributing factor to doctoral learners dropping out before completing their program (Ali \& Kohun, 2006; Lovitts 2001). Consequently, many online students are susceptible to feelings of seclusion because they do not meet face-toface with instructors and peers. This context provides the basis for the value of incorporating technological advances in doctoral programs to foster connectivity, reduce isolation, and promote retention.

Existing research portrays a disturbing picture of doctoral departure, although private online workspaces demonstrate promise for improving doctoral retention. Dissertation support, program support, and faculty support influence attrition (Kennedy, Terrell, \& Lohle, 2015). Missing from the current research is a study examining the use of technology during the dissertation process, and whether the application can improve outcomes. Implementing the private doctoral workspace embraces new technology to offer support for learners. What is not known is whether using this technology can demystify and improve the students' lengthy, complex, and often lonely dissertation experience. Effective strategies are needed to address lower persistence and retention levels in online programs (Berman et al., 2012). The landscape of online doctoral education is rapidly transforming due to technological advances. Virtual scholarly communities can be created for doctoral learners designed to support academic success for online learners (Berman, Bainbridge, \& Kilroy, 2010). It is unknown, however, whether providing a dedicated workspace for every dissertation student can increase communication and engagement, and reduce isolation.

\section{Methodology}

\section{Background}

Effectively combating doctoral attrition was the catalyst for developing the Doctoral Community Network (DC), an online scholarly community that helps doctoral learners successfully finish their dissertation and program of study. The DC provides a comprehensive catalog of support services to guide and assist new researchers as they learn the process, terminology, tools, and norms to become independent scholars, capable of producing independent high-quality research. Learner access provides timely content written by experts in the fields of quantitative research, qualitative research, and technology. Using a collaborative technology, the DC offers a mechanism for new researchers to receive feedback on prospective research ideas from the research community. When a learner uses the DC and posts online, other learners, faculty, and the fulltime doctoral librarian provide feedback, suggestions, and references.

Private doctoral workspaces are an extension of the DC and have been created exclusively for learners preparing their dissertation. The learner, the dissertation chair, the methodologist, the content expert, and the external reviewer access shared resources in the private doctoral workspace. Together they can easily communicate, share and review manuscript versions, and plan specific milestones towards the successful completion of the learner's dissertation. Communications, milestones, and document versions that reside on the private doctoral workspace remain intact throughout the duration of the learner's dissertation process.

This study used convenience sampling to distribute a seven question survey to 803 doctoral learners who each has access to their own private doctoral workspace. The learners completed their coursework and were in the dissertation phase of their program. The survey measured frequency of access to the private doctoral workspace, perceptions of isolation, and learner engagement and communication with the dissertation committee. The learners were from a private Christian uni- 
versity in the southwestern United States. Learners obtained access to the private doctoral workspace on the following dates:

$\begin{array}{ll}12 / 4 / 2013 & 30 \text { students } \\ 2 / 3 / 2014 & 34 \text { students } \\ 2 / 12 / 2014 & 50 \text { students } \\ 3 / 5 / 2014 & 107 \text { students } \\ 4 / 1 / 2014 & 110 \text { students } \\ 4 / 8 / 2014 & 211 \text { students } \\ 4 / 25 / 2014 & 266 \text { students }\end{array}$

In the initial June survey, three requests for participation were sent by email, and reminders for participation were posted in the DC. Three requests for participation were also sent in the followup October survey, four months later. Of the 803 surveys distributed in June to Doctor of Philosophy (PhD), Doctor of Education (EdD), and Doctor of Business Administration (DBA) students, 328 were returned, a 40\% response rate. In October, 803 surveys were again distributed, and 190 were returned, resulting in a $24 \%$ response rate. Due to minimal participation, the DBA and $\mathrm{PhD}$ responses were eliminated, and only the EdD responses were used in the final analysis. There were only five DBA responses in the initial June survey, and one DBA response in the follow-up October survey. Similarly, there were $40 \mathrm{PhD}$ responses in June, and only $11 \mathrm{PhD}$ responses in October. The number of EdD responses resulted in a larger number of respondents, with $328 \mathrm{EdD}$ responses in June, and 190 responses in October.

A decision was made not to request personal identifiers for the study. It was believed that asking participants to provide specific impressions of their dissertation chair and committee would unduly influence the learner responses, and thereby bias the study. Although responses were obtained from the same population, different individuals may provide responses to the pre and post studies. Without identifiers, the execution of a paired t-test would not be possible. Additionally, a significant difference in the response rate from the pre and post surveys would further limit the execution of other statistical tests. However, since this research was designed as a preliminary study to assess initial usage and value of the private workspace, the use of descriptive statistics was considered sufficient, and would not detract from the overall results. Future studies could include identifiers that would enable statistical testing.

Each survey was accompanied by an explanation for the purpose of the survey. The survey contained seven questions (See the Appendix). Participants were asked to provide information on the following: three demographic questions, three questions using a 5-level Likert rating scale (ranging from strongly disagree to strongly agree), and one question relating to student log on (never, 1 time per week, 2 or more times per week, or unaware of the page). The survey concluded with an option for students to include their name and email if they wanted to be considered for additional related research. The following variables were used as they were deemed most relevant: Usage of the private doctoral workspace, communication with the dissertation committee, and feelings of isolation.

To assess the variables listed above, the following research questions were addressed:

R1: How frequently do doctoral learners seek interaction via private online workspaces?

$\mathrm{R} 2$ : Does interaction in a private online workspace reduce doctoral learner perception of isolation?

R3: Do private online workspaces help doctoral learners to communicate more effectively with their dissertation committee? 


\section{Results}

The raw data was imported from the SNAP survey using Statistical Package for Social Sciences (SPSS) software. The data were screened for errors in data entry, outliers, and distribution. Variables were measured to determine if significant differences existed

Research Question \#1: How frequently do doctoral learners seek interaction via private online workspaces?

Overall, as shown in Table 1, 39.3\% of the population of EdD learners who responded to the initial survey indicated they logged onto their private doctoral workspace at least once a week. In the post survey, the percentage of EdD learners increased to $87.7 \%$.

Table 1. Percent of learners who log onto their private doctoral workspace at least once per week.

\begin{tabular}{ccccc}
\hline & $\begin{array}{c}\text { Pre Survey } \\
\text { Responses }(n)\end{array}$ & $\begin{array}{c}\text { Post Survey } \\
\text { Responses }(n)\end{array}$ & Pre (\%) & Post (\%) \\
\hline Dissertation & 174 & 178 & $39.3 \%$ & $87.7 \%$ \\
\hline
\end{tabular}

Research Question \#2: Does interaction in a private online workspace reduce doctoral learner perception of isolation?

As reported in Table 2, 23.1\% of the population of EdD learners who responded to the initial survey reported reduced feelings of isolation. In the post survey, the percentage increased to $27.6 \%$.

Table 2. Percent of learners who indicate their private doctoral workspace helps to reduce isolation during the dissertation phase.

\begin{tabular}{ccccc}
\hline & $\begin{array}{c}\text { Pre Survey } \\
\text { Responses }(n)\end{array}$ & $\begin{array}{c}\text { Post Survey } \\
\text { Responses }(n)\end{array}$ & Pre (\%) & Post (\%) \\
\hline Dissertation & 227 & 156 & $23.1 \%$ & $27.6 \%$ \\
\hline
\end{tabular}

Research Question \#3: Do private online workspaces help doctoral learners to communicate more effectively with their dissertation committee?

As shown in Table 3, 25.5\% of the population of EdD learners who responded to the initial survey reported increased communication with their dissertation committee. In the post survey, the percentage increased to 37.6

Table 3. Percent of learners who indicate their private doctoral workspace helps them communicate more effectively with their dissertation committee.

\begin{tabular}{ccccc}
\hline & $\begin{array}{c}\text { Pre Survey } \\
\text { Responses }(n)\end{array}$ & $\begin{array}{c}\text { Post Survey } \\
\text { Responses }(n)\end{array}$ & Pre (\%) & Post (\%) \\
\hline Dissertation & 226 & 154 & $25.5 \%$ & $37.6 \%$ \\
\hline
\end{tabular}

\section{Discussion and Recommendations for Future Study}

This study is consistent with prior research that reveals that interconnectedness and interactions with others are critical components of dissertation completion (Baker et al., 2013; Rovai, 2002). Not surprisingly, this study also illustrates that providing learners with support and resources provides clarity for novice researchers, reduces feelings of isolation, and increases communication between learners and their dissertation committee. The use of technology is becoming increasingly important in supporting doctoral education (Rockinson-Szapkiw, 2012), and this study attempts to offer guidance in the development of an effective technological intervention. Because the private doctoral workspace new, it is encouraging to learn that preliminary data indicate usage of the private doctoral workspace is increasing. During the dissertation process, many students 
are working virtually; therefore, student communication is typically in an online format (Terrell, Snyder, Dringus, \& Maddrey, 2012). Implementing the online workspace for doctoral learners is one way to address the needs of doctoral learners, many of whom work on their dissertation virtually. The introduction of the private doctoral workspace and the results assessed through learner surveys occurred within a relatively short time span of four months; therefore, the long term value is not yet known. The authors speculate that as learners and faculty become more familiar with the private doctoral workspace, it will further reduce isolation, increase connectivity, and ultimately enhance the learner experience, which may lead to higher rates of retention.

Student and faculty expectations must align because perceived lack of support by faculty and the institution can cause learners to drop out (Martinsuo \& Turkulainen, 2011). The increase in log on rates when using the private doctoral workspace may be attributed to faculty and learner acceptance of the private doctoral workspace as a convenient way to communicate with members of the dissertation committee. The increase in log on rates may also be due to faculty and learners understanding the benefits of having a central repository for storing research related documents. The private doctoral workspace automatically saves and distributes email communications to all members of the learner's dissertation committee, which helps makes it the de facto center for the learner's research initiative. Another factor which may contribute to an increase in usage was that faculty and learners were asked by administrators to use the private doctoral workspace for the majority of their communications as related to the dissertation. Usage was not mandatory, but highly encouraged.

Prior to the creation of the private doctoral workspace, faculty and learners communicated almost exclusively through email. Additionally, email communications were often sent exclusively between the chair and the learner, and frequently did not include all members of the dissertation committee. This approach frequently led to confusion by the dissertation committee members, which often materialized as the learner approached the request for approval of prospectus and proposal. Without documented long-term dissertation communication records and document versions, any changes in research direction, methodology, or scope were problematic for the dissertation committee members. In environments that are less supportive, learners are less likely to complete their program of study (Gardner, 2010). Offering the private doctoral workspace helps to mitigate learner uncertainty and feelings of isolation by providing guidance, a document repository, resources, and a platform for communication.

There are several limitations to this study. This study reflects solely on the university in question along with its curriculum, faculty, and its unique online support structure. The survey of doctoral learners encompasses one private Christian university, limiting the demographic sample. The results may not be generalizable to other doctoral programs at other universities without additional research. Moreover, the unique survey was created by the lead researcher and has not been validated.

This study represents one portion of the university's longitudinal study that addresses improvement of the doctoral experience and program to ultimately reduce doctoral attrition. Findings from this study provide a foundation for future research to determine (a) if usage of a private doctoral workspace varies by learner age, (b) if isolation changes over time and varies by learner age, (c) if adding video conferencing to the private doctoral workspace affects learner perception of isolation, and (d) what is of value to doctoral learners (i.e., dissertation content, professional relationship, personal relationship, methodology assistance, or literature review). Additionally, more research is needed to assess (a) faculty perceptions of the private doctoral workspace, (b) faculty perception of those factors that influence learner dissertation progress during the dissertation, (c) faculty perceptions of those factors that influence positive learner communications in the dissertation phase, and (d) what is important to faculty chairs (i.e., dissertation content, professional relationship, personal relationship, methodology assistance, or literature review). Finally, future stud- 
ies could include identifiers for learners and dissertation chairs enabling statistical testing. Continued research assessing the value of adding planned dissertation milestone dates into the calendar of the private doctoral workspace, is also recommended.

\section{Conclusions}

Preliminary data indicate learners frequently access their private dissertation workspace, which was created for learners and their dissertation committee. With this access, learners state they communicate more effectively with their committee and with faculty and report reduced isolation during the dissertation process. To reduce isolation, it is critical to foster collaboration between faculty and learners. Faculty should remember the tenuous nature of the independent dissertation phases and remain in close contact with their advisees (Gardner, 2008). Isolation is a significant factor adversely influencing the completion of the dissertation in the doctoral program of study. The findings of this exploratory study reveal that access to a private dissertation workspace is beginning to reduce isolation and is enabling doctoral learners to communicate more effectively with members of their dissertation committee. The challenges of independent doctoral research coupled with the lack of learner experience amplify the need for on-going communication between the learner and their dissertation committee. The use of private workspaces for doctoral learners completing a detailed long-term project shows promise. This approach may also be applied to other disciplines - master's thesis, independent study, group projects performed at the undergraduate level, and in business.

\section{References}

Ali, A., \& Kohun, F. (2007). Dealing with social isolation to minimize doctoral attrition-A four stage framework. International Journal of Doctoral Studies, 2(1), 33-49. Retrieved from http://www.ijds.org/Volume2/IJDSv2p033-049Ali28.pdf

Allen, I. E., \& Seaman, J. (2010). Class differences: Online education in the United States. Needham, MA: Babson Survey Research Group.

Allen, I. E., \& Seaman, J. (2011). Going the distance: Online education in the United States. Sloan Consortium.

Baker, V. L., Pifer, M. J., \& Flemion, B. (2013). Process challenges and learning-based interactions in stage 2 of doctoral education: Implications from two applied social science fields. The Journal of Higher Education, 84(4), 449-476. Retrieved from http://dx.doi.org/10.1353/jhe.2013.0024

Berman, R., Bainbridge, C., \& Kilroy (2010). Building an online scholarly collaboration network. Unpublished White Paper. Grand Canyon University, College of Doctoral Studies.

Berman, R., Grant, G., \& Markette, N. J. (2012). Doctoral community network: A case study of the perceptions of doctoral learners regarding a private, scholarly earning community. Journal of Educational Technology, 10(3), 1-11.

Berman, R., Radda, H. \& Cross, T (2013). The impact of a voluntary scholarly community on online students. Presentation at the Sloan-C 19th Annual Consortium - International Conference on Online Learning, Lake Buena Vista, Florida, November 20-22, 2013.

Bollinger, D. U., \& Inan, F. A. (2012). Development and validation of the online student connectedness survey. The International Review of Research in Open and Distance Learning, 13(3). Retrieved from http://www.irrodl.org/index.php/irrodl/article/view/1171

Council of Graduate Schools. (2008). Ph.D. completion and attrition: Analysis of baseline demographic data from the Ph.D. completion project. Washington DC.

Council of Graduate Schools. (2010). PhD completion and attrition: Policies and practices to promote student success. 
DeVaney, T. A. (2010). Anxiety and attitude of graduate students in on-campus vs. online statistics courses. Journal of Statistics Education, 18(1), 1-15.

Fiegener, M. K. (2011). Number of doctorates awarded in the United States declined in 2010 [Report No. NSF 12-203]. Retrieved from National Science Foundation, National Center for Science and Engineering: www.nsf.gov/statistics/

Gardner, S. K. (2008). "What's too much and what's too little?" The process of becoming an independent researcher. The Journal of Higher Education, 79(3), 326-350. Retrieved from http://dx.doi.org/10.1353/jhe.0.0007

Gardner, S. K. (2010). Contrasting the socialization experiences of doctoral students in high and low completing departments: A qualitative analysis of disciplinary contexts at one institution. The Journal of Higher Education, 81(1), 61-81. Retrieved from http://dx.doi.org/10.1353/jhe0.0081

Golde, C. M. (2005). The role of the department and discipline in doctoral student attrition: Lessons from four departments. Journal of Higher Education, 76(6), 669-700. Retrieved from http://dx.doi.org/10.1353/jhe.2005.0039

Golde, C. M., \& Dore, T. M. (2001). At cross purposes: What the experiences of doctoral students reveal about doctoral education. Philadelphia, PA: A report prepared for the Pew Charitable Trusts.

Greenberger, S. W. (2012). Applying the dualistic model of passion to post-secondary online instruction: A comparative study (Doctoral dissertation).

Hachey, A. C., Wladis, C. W., \& Conway, K. M. (2012). Is the second time the charm? Investigating trends in online re-enrollment, retention and success. Journal of Educators Online, 9(1), n1.

Holmes, B. D., Robinson, L., \& Seay, A. D. (2010). Getting to finished: Strategies to ensure completion of the doctoral dissertation. Contemporary Issues in Higher Education Research, 103(7).

Kennedy, D. H., Terrell, S. R., \& Lohle, M. (2015). A grounded theory of persistence in a limitedresidency doctoral program. The Qualitative Report, 20(3), 215-230.

Lovitts, B. E. (2001). Leaving the ivory tower: The causes and consequences of departure from doctoral study. Lanham, MD: Rowman \& Littlefield.

Lovitts, B. E. (2005,). Being a good course-taker is not enough: A theoretical perspective on the transition to independent research. Studies in Higher Education, 30(2), 137-154. Retrieved from http://dx.doi.org/10.1080/03075070500043093

Martinsuo, M., \& Turkulainen, V. (2011). Personal commitment, support, and progress in doctoral studies. Studies in Higher Education, 36(1), 103-120. Retrieved from http://dx.doi.org/10.1080/03075070903469598

McCracken, H. (2009). Best practices in supporting persistence of distance education students through integrated web-based systems. The Educational Technology Journal, 10(1), 65-91. Retrieved from http://dx.doi.org/10.2190/cs.10.1.f

Moore, M. G., \& Kearley, G. (2012). Distance education: A system view of online learning (3rd ed.). Retrieved from $\underline{\text { http://books.google.com/books? id=wXtsKAMiuAAC\&dq=distance+learning }+ \text { history\&lr }=\& \text { source }=\mathrm{gb}}$ S_navlinks_s

Radda, H. \& Berman, R. (2012). Creating an online community of doctoral learners through innovative scholarly networking. Presentation at the SLOAN-C 5th Annual International Symposium Emerging Technologies for Online Learning, Las Vegas Nevada. July 25-27, 2012.

Rockinson-Szapkiw, A. J. (2012). Investigating uses and perceptions of an online collaborative workspace for the dissertation process. Research in Learning and Technology, 20(0). Retrieved from http://dx.doi.org/10.3402/rlt.v20i0.18192

Rovai, A. P. (2002). Development of an instrument to measure classroom community. Internet and Higher Education, 5(3), 197-211. Retrieved from http://dx.doi.org/10.1016/s1096-7516(02)00102-1 
Saba, F. (2011). Distance education in the United States: Past, present, future. Educational Technology, $51(6), 11-18$.

Smallwood, S. (2004, January 16). Doctoral dropout. The Chronical of Higher Education. Retrieved from http://chronicle.com/article/Doctor-Dropout/33786/

Stallone, M. N. (2011). Factors associated with student attrition and retention in an educational leadership doctoral program. Journal of College Teaching and Learning, 1(6), 17-24.

Sull, E. C. (2013, January 31). Student engagement in the online classroom. The Chronicle of Higher Education. Retrieved from http://chronicle.com/article/Student-Engagement-inthe $/ 136897 /$ ?cid=ja\&utm source=ja\&utm medium=en

Terrell, S. R., Snyder, M. M., Dringus, L. P., \& Maddrey, E. (2012). A grounded theory of connectivity and persistence in a limited residency doctoral program. The Qualitative Report, 17(62), 1-14. Retrieved from http://www.nova.edu/ssss/QR/QR17/terrell.pdf

\section{Appendix \\ Grand Canyon University \\ Learner Dissertation Survey}

In an effort to evaluate and continually improve the curriculum at Grand Canyon University, we are asking you to complete this brief survey. Your feedback is vital to the value of quality programs. There are no "right" or "wrong" answers; what is important is the information you provide. This survey is administered and maintained by the Office of Assessment, which guarantees your confidentiality.

1. Please identify your Program of Study.

$\begin{array}{ll}\circ & \text { EDD } \\ \circ & \text { DBA } \\ \circ & \text { PHD }\end{array}$

2. Please identify the year of your Program start.

○ 2008

○ 2009

○ 2010

○ 2011

○ 2012

3. Please identify your current Dissertation Course.
○ DIS 955-965
○ DIS 966-968
○ DIS 969-075
○ PSY 966-968
○ PSY 969-075
- Other

4. I log on to my Learner Dissertation Page*

- Never

- 1 time per week

- 2 or more times per week

- I am not aware I have access to my Learner Dissertation Page 
5. My Learner Dissertation Page in the Doctoral Community Network helps me reduce isolation during the dissertation phase.

- Disagree strongly

- Disagree

- Neither agree nor disagree

- Agree

○ Agree Strongly

6. The Learner Dissertation Page in the Doctoral Community helps me to communicate more effectively with my dissertation committee.

- Disagree strongly

- Disagree

- Neither agree nor disagree

- Agree

- Agree Strongly

7. Optional: Please add you name and email if you would consider being included in additional related research.

*The term Learner Dissertation Page was used in the survey. For the purpose of this article, the term Private Doctoral Workspace was used as it is more descriptive.

\section{Biographies}

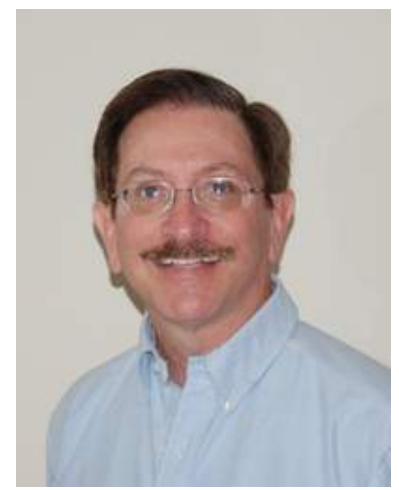

Ronald Berman is Executive Director and Assistant Professor at Grand Canyon University, College of Doctoral Studies in Phoenix, Arizona. Dr. Berman is responsible for overseeing the development and implementation of long-term strategies that enhance the effectiveness of Doctoral Education at Grand Canyon University. He is the primary architect of the Doctoral Community Network and has research interest in virtual learning communities, research processes, and strategic directions to enhance retention of doctoral learners. He participates in doctoral dissertation committees and teaches innovation, leadership, technology, and analytics in the colleges' education, business, and psychology doctoral programs. E-mail: ronald.berman@gcu.edu

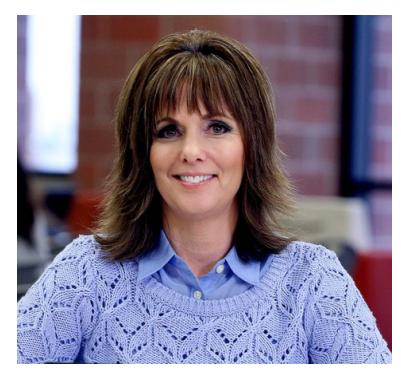

Cathy Ames is pursuing a Doctorate of Education in Organizational Leadership at Grand Canyon University, with an emphasis on Organizational Development. She was previously an elementary teacher and Vice Principal. Her research interests include doctoral attrition, connectivity, and communication. Email: cames1818@gmail.com 